\title{
Pedagogy of the consumer: The politics of neo-liberal welfare reform
}

\section{Andrew Wilkins}

Abstract: Situated against the backdrop of a widespread and growing interest in the linkages between neo-liberalism and welfare, this paper introduces the lens of neo-liberalism as a conceptual strategy for thinking about contemporary issues in education policy. Through charting the historic rise of unfettered market institutions and practices in the context of 1980s England, it highlights the cultural and geopolitical specificity affixed to nation-based articulations and translations of neo-liberalism. Building on this perspective, it considers how market discourses with its pedagogy of the consumer shape a plurality of education sites and practices. To follow, it sets out the specific contributions by authors to this interdisciplinary collection of papers on the themed issue of neo-liberalism, pedagogy and curriculum. It identifies the contexts for their analyses and discusses the implications of their approaches for better mapping the 'global' impact of neo-liberalism on welfare states and peoples, specifically the full range of policy enactments and disciplinary practices shaping education customs of pedagogy and curriculum.

Key words: pedagogy, consumer, neo-liberalism, politics, education

\section{Neo-liberalism: One - size - fits - all?}

Over the last twenty years or so numerous commentators (chief among them Marxist and Foucauldian scholars, social policy analysts and critical geographers, social anthropologists and sociologists of education) have turned their attention to documenting the effects of neo-liberalism on different welfare states, economies and peoples. Neo-liberalism can refer to a set of propositions and applications consisting of dynamics drawn from what are sometimes considered separate spheres of activity or knowledge, e.g. public and private, citizen and consumer, state and market, global and local (Clarke et al., 2007; Wilkins, 2010; 2012a). Hence the arrival of hybridised and convoluted vernacular like "citizen-consumer", "mixed economy", 
"pseudo-market" and "glocal" (referring to the coupling of global and local trends). As such studies on neo-liberalism utilise and combine diverse methodologies and epistemologies in order to reflect the porous terrain of their subject matter. This is best reflected through the myriad topics that make up a number of important studies on neo-liberalism, ranging from the changing formation of welfare and citizenship (Olssen, Codd \& Neil, 2004; Ong, 2006; Rose, 1999; Wacquant, 2009) and the liberation of financial structures and global elites (Harvey, 2005) to the displacement of citizen-based practices of democratic participation (Brown, 2006; Giroux, 2011) and the reorganisation of urban environments and space (Boudrea, Keil \&Young, 2009; Ferguson \& Gupta, 2002; Peck \& Tickell, 2002). These diverse conceptual approaches and empirical analyses have resulted in promising dialogue together with knowledge transfer and exchange across a plurality of disciplines, institutions, sites and spaces, culminating in greater and more nuanced discussions of the 'global' impact of neo-liberal trends. This has also contributed positively to generating more robust accounts of the discursive (e.g. policy, attitudinal, behavioural) and material (e.g. institutional, spatial or geographical) effects of neo-liberalism on different welfare states and cultural traditions.

Global approaches to understanding neo-liberal trends are problematic, nonetheless. The historical and geopolitical specificity underpinning articulations of neo-liberalism suggest that global approaches are likely to produce reductionist analyses of the cultural forms and struggles that embed neo-liberal forms of transformation. This is partly because neo-liberal rhetoric mediates a paleo-liberal or libertarian view of market institutions as freestanding entities, with the implication that cultural forms are treated as epiphenomenal and secondary to the 'self-correcting' impulses of the market. It is thus crucial that analysts do not replicate the insignia of the market as a basis for their studies of neo-liberalism, but rather engage critically with the cultural forms and relations that underpin its articulation and mobilization. Gray reminds us for example that "Market liberalism, like other Enlightenment ideologies, treats cultural difference as politically marginal phenomenon whose appropriate sphere is private life" (2007, p. 154). When posited through Enlightenment framings of 'universalism' and 'progress', therefore, neo-liberalism can only be generically grasped at the level of codes, guidelines and procedures which are judicial, economic or legislative in nature. To put it crudely, these frameworks constitute abstract systems of rules and norms and therefore say little about how neo-liberalism is lived and produced through the activity of historical agents and institutional practices. Holland and Lave (2000), for example, demonstrate how cultural forms mediate a structured social existence that is historically produced 
and struggled over through the quotidian activities echoed through everyday practices and relations. To engage neo-liberalism at both the discursive and material level - and to understand its unintended and multifarious effects means making sense of the politics and struggles through which neo-liberal forms are imbued with social-cultural and institutional force. Later on I will demonstrate how the contributing authors to this special issue engage with a similar set of issues through drawing connections between the politics, policy and practice underpinning neo-liberal reform. In the meantime I want to consider the conditions of possibility that gave rise to the emergence of neo-liberalism in the context of 1970s England. This foregrounds the importance of context for reading neo-liberal discourse as a political-cultural project bound to geopolitical-based skirmishes, allegiances and articulations.

\section{Neo-liberalism: Discourse, Framing and Function}

Broadly conceived, neo-liberalism signifies a political, intellectual and economic trend or movement originating in the fiscal, energy and debt crises that characterised the 1970s. In the context of 1970s England, for example, a particular set of cultural and historical circumstances gave rise to neoliberalism as a formidable intellectual and political force. The etchings of neo-liberalism first started to emerge in England when corporatist policy which refers to those policy making mechanisms that traditionally mediated relations between the government, businesses and the trade unions - was brought under intense pressure from the fiscal challenges facing the government. High inflation coupled with economic stagflation gripped the nation and the ability of governments to sustain a balance between wages and the cost of living for the majority of its citizens was quickly undermined by liberal economists and political conservatives together with the support of the right-wing think tank Centre for Policy Studies (established in 1974).

The endurance and legitimacy of Keynesian fiscal policy as a political and economic settlement for managing welfare state capitalism was effectively toppled by a new historical bloc comprised of Right-liberal economic and political interest groups (Gray, 2007). Keynesian tendencies towards central planning of the state and economy - traditionally held together in England through "harmony between Ministers, sponsoring departments, institutions and the public" (Middlemas, 1986, p. 342) - underwent intense scrutiny during this period as Labour and Conservative governments failed to control inflation (inflation peaked at $26 \%$ in July 1975). The conventional practice of using public spending to improve the demand for output and employment was deplored by its opponents as inefficient and wasteful (Hirschman, 1991). This led to a torrent anti-statist rhetoric coupled with a surge of inter- 
est in the monetarist doctrine devised and championed by Milton Friedman (1970), the central idea being that Keynesian demand management forced the debasement of the currency and exhausted the capacity of markets to be flexible and dynamic. United under the auspices of a relatively coherent programme of governance that later came to be termed New Right and neoliberal (Millar \& Rose, 2008), admonishment of Keynesian fiscal policy was eventually secured through the landslide victory of Thatcher's neo-conservative government in 1979 .

The term neo-conservative is important here for designating the particular rupture or break that severed traditional British conservatism, notionally occupied with ideas of "non-progress", "anti-universalism" and the "primacy of cultural forms" (Gray, 2007, pp. 161-163), from Thatcher's Conservative government with its insistence on the progressive character of market institutions and the "liberal individualist fiction of the disembodied or unsituated human subject” (Gray, 2007, p. 24). Neo-liberal discourse in effect served as a discursive framework for steering welfare politics, policy and practice away from post-war, "socio-liberal" commitments. The focus of these commitments included making sure citizens "enjoyed a minimum level of rights (economic security, care, protection against various risks and so on)" (Johansson \& Hvinden, 2005, p. 106). Instead the government carved out a competitive and deregulated space with the expectation that citizens would inhabit and perform the role of consumers and comply with an ethics of self-care as responsible, self-regulating subjects (Deacon, 1994). As these welfare developments were beginning to take shape in the context England, similar emerging trends could be witnessed in the United States under the presidential authority of Regan (see Brown, 2006 for a discussion of the rise of neo-liberalism and neo-conservatism in the US).

In the terrain of education policy and practice, the Thatcher government initiated a number of key policy reforms envisioned to generate a marketled system of education provision and to shore up acceptance in the virtue of private sector involvement in public sector organisation, with its appeals the efficiency of markets, the liberty of individuals and the non-interventionist state' (Keat \& Abercrombie, 1991, p. 1). New legislation - the 1980 and 1986 Education Acts and notably the 1988 Education Reform Act (ERA) - contributed significantly to these achieving these ends, namely through reframing the relationship between parents and schools into a contractual one between consumers and providers. This is evidenced by the increased emphasis on diversity of provision and parental choice at the time together with the introduction of local business interests to the composition of governing bodies and the improved capacity for schools to become administratively self-governing (Gewirtz, Ball \& Bowe, 1995; Lowe, 2005). 
Other nations, too, exemplify related education trends, albeit within nationally-defined political processes and policy frameworks. Similar to England, Sweden for example sustains a mixed economy of welfare with expanded roles for private, voluntary and informal sectors in the content and delivery of education provision. In much the same way that England rolled out marketisation and competition as policy devices for frustrating the efforts of any form of centrally planned education system, Sweden implemented elements of a 'quasi-market' during 1991-1994 primarily as a means of overturning the state monopoly of education provision (e.g. the voucher system in 1992). This in turn gave rise to free (e.g. state-subsidised, privately run) schools, school choice and diverse forms of education provision (Holm \& Arreman, 2011) (also see the charter school movement established in the US in 1988). In other Scandinavian countries, such as Denmark and Norway, there is further evidence of traditionally central planning institutions being transplanted to make way for the insertion of free-market policy discourses and relations in the field of education. Alongside advanced liberal countries like Australia, New Zealand, Canada and the US, a raft of market-driven education policy initiatives are also discernible in the education systems governing post-communist nations, in particular the Visegrád countries: Hungary, Poland, the Slovak Republic and the Czech Republic (see Kaščák \& Pupala, 2011).

Yet despite the co-existence of these analogous systems of market-driven education, the endurance and sustainability of neo-liberalism as a political and economic reality will in the end be determined by the cultures and peoples it supposedly serves. This is paramount to any theoretically and empirically useful discussion of "global" neo-liberal trends since it identifies "the different modes of insertion into "global" neo-liberalism that are experienced by different regions, nations, and more local places" (Clarke, 2008, p. 137). As Gray similarly observes, this "should make us sceptical of the claims of any model for market institutions, and of any mode of policy which is based on the tacit assumption that there is a single ideal-typical form of market institutions to which all economies will, should, or can, approximate" (2007, p. 58). From this perspective, governmentality approaches to understanding neo-liberal policy trends (see Millar \& Rose, 2008) can be accused of sometimes occluding or sidestepping important engagements with questions concerning the social and the cultural practices that embed as well as impede neo-liberal reform strategies. Governmentality approaches - or what Barnett et al. label "functionalist narratives of neo-liberalization" (2008, p. 628) - appear to insist on the efficacy of "epistemes" or governmental rationalities to constitute subjects or at least limit the motivations and orientations people exercise (Bevir, 2007). As Newman observes, "the governmentality 
perspective [therefore] does not readily lend itself to an understanding of the social - in particular, how new governmentalities are limited and how people respond to the subject positions that are discursively produced" (2007, p. 53).

Neo-liberal policy discourse can therefore be more richly conceptualised in contingent terms as bound to shifting conditions of possibility, translation and re-articulation (see Peck, 2004). In other words, the capacity of historical agents to resist and contest the interpellative demands of different governmentalities needs to be emphasised for any dynamic and situated reading of neo-liberalism to be achieved. Such a view forms the centrepiece argument for this themed issue. It aims to move away from any reductive, one-size-fits-all vision of neoliberalism as a stable and unitary 'global' phenomenon and instead foregrounds context in order to make sense of the internal complexities and geohistorical specificity underpinning the formation of neo-liberal discourses, particularly as they relate to the changing representation of pedagogy and curriculum in the field of education.

\section{Pedagogy of the Consumer}

In the context of education pedagogy can be broadly conceived as a function and discourse of power through which customs and norms are exercised and moderated to provisionally stabilize hegemonic systems of political, economic and cultural rule. A useful definition is offered by Giroux when he compares pedagogy to "an educational site where identities are being continually transformed, power is enacted, and learning assumes a political dynamic as it becomes not only the condition for the acquisition of agency but also the sphere for imagining oppositional social change" (Giroux, 2004, p. 6). Pedagogy therefore is akin to the reproduction of cultural and linguistic systems of domination and discipline (Freire, 1970); a repeated stylization of cultural norms and communication practices held together through a highly rigid regulatory framework imbued with established hierarchy. As such, pedagogy and curriculum are not mutually exclusive customs but powerfully inform and shape each other. This is evident when we consider the ways in which pedagogy and curriculum intersect to produce representations and specifications of school ethos, provision, needs and delivery (usually defined with specific 'peoples' and 'communities' in mind, see Wilkins, 2012a). Viewed in this way pedagogy is never entirely value neutral since it is implicated in the practice and valorisation of certain ontologies and epistemologies over others, e.g. ways of interpreting, understanding and applying knowledge to the world and to constructions of subjectivity (Burke, 2012; Mclean, 2006). This had led some researchers, following Freire (1970), 
to highlight the implicit classed, gendered and even racialized assumptions engendered through pedagogic practices and to engage with the challenges of developing inclusive pedagogies which accommodate the social and cultural backgrounds of different learners (Mann, 2005; Fanghanell, 2007). More recently, researchers have discussed the impact of neo-liberal styles, rhetoric and disciplinary forms as dynamics structuring classroom-based pedagogic discourses and obligations (see Mccafferty, 2010; Wilkins, 2012d). Specifically, they address how market-driven discourses with its pedagogy of the consumer mediate school-based pedagogic norms and values. Continuing in this critical vein, the contributing authors to this special issue analyse the interconnections between neo-liberalism, pedagogy and curriculum from the perspective of policy discourse and development in their respective countries, and open up meanings of pedagogy and curriculum to new understandings and conceptualisations.

The first of these authors, Burke, traces the relationship between Catholic religious and corporate interests in the context of market reforms to education systems in the US. Much like the UK and other advanced liberal countries, the US government seeks to cut public spending to education by generating greater links between schools and wider networks of private funders and sponsors, e.g. philanthropists, universities and corporations. Burke unpacks some of these issues through interrogating the changing landscape of Catholic religious education in the US, specifically 'the increasing alignment of Catholic schooling with neoliberal marketized reforms'. Burke observes within these trends a deeply unsettled conflation of education goals with political and economic objectives, a corollary of which is that traditional Catholic pedagogical and religious-moral customs are negotiated alongside neoliberal conceptions of economic utility and efficiency. The focus of the following article by Robbins and Kovalchuk engages with a similar set of topics through exploring the implicit and explicit assumptions underpinning the pedagogical arrangements that make up contemporary forms of schooling in the US. Drawing strength from the insights generated through analyses of the 'hidden curriculum', Robbins and Kovalchuk trace the complicity of certain forms of school-based surveillance, punishment and discipline as elements framing the criminalization of youth subjects. In particular, they uncover the links between neo-liberal governance and racial politics by illustrating how pedagogical norms and school-based intervention programmes, such as Positive Behaviour Interventions and Support (PBIS), reinforce rather than undercut elements of racial profiling.

In the following article, Frauley draws on the lens of Foucauldian analytics to explore the concept of employability as a regulatory feature of higher education institutions in context of education policy and practice in Ontario, 
Canada. Drawing attention to the narrow instrumentalist conception of education that frequently pervades Canadian government policy discourse, Frauley considers employability as a constitutive element in the structuring of higher education institutions and to the formation of subjectivities more generally. Specifically, Frauley builds on the governmentality literature to suggest that 'employability is not a quality of person, an outcome of skilling or the acquisition of economic capital. It is a category of governance'. As Frauley demonstrates, employability as a framing and function of education can be traced to the ways in which schools ascribe value to entrepreneurial literacies and skills. In a similar vein, Dahlstedt and Hertzberg explore the rise of entrepreneurialism in the context of Swedish education policy discourse and trace its discursive effects to the changing representation and specification of pedagogy and curriculum. Through highlighting the political and economic rationalities underpinning recent Swedish government policy texts, Dahlstedt and Hertzberg underscore the sovereignty of the figure of the entrepreneur. Specifically, Dahlstedt and Hertzberg connect these trends to wider transnational shifts geared towards neoliberal or advanced liberal modes of governing. For example, Dahlstedt and Hertzberg capture the ways in which Swedish education policy development is inscribed with the needs and demands of the labour market at its centre. In this framing, entrepreneurship emerges 'not as a priority of education policy, but rather as something necessary or compulsory'.

Martin closely follows the theme of Dahlstedt and Hertzberg's article by animating a discussion on the deep interconnections between education and training and the needs of labour markets in the context of Ontario, Canada. Martin draws close attention to the insignia of 'corporatism' as a framework which links school performance to the stability of the economy and helps to legitimate a narrow view of students as workers/producers. Continuing with the theme of marketisation and commodification, Savage closely examines how certain schools in Melborne, Australia engage in practices of corporate branding and provision tailoring. Noting how many schools rely on promotional strategies to differentiate themselves as unique in an increasingly competitive field of school choice, Savage alludes to the paradoxical claims of governments that require schools to 'be simultaneously different and the same'. To illustrate this Savage highlights how branding techniques can sometimes serve to steer provision away from the perceived needs of local communities and thus, ironically, undermine the government project of tailoring and personalisation.

By way of denoting the unrelenting barrage of attacks pursued by governments in toppling the imagery of public welfarism, the final article by Gounari and Grollios examines the state of higher education in Greece and 
traces the policy rhetoric underpinning the Greek government's admonishment of 'public' institutions. In the style of a policy discourse analysis, Gounari and Grollios engage with a number of key policy texts to uncover the rhetorical devices through which the Greek government intend to undermine public ownership of higher education institutions and instigate neoliberal reform. Each of the above authors introduce a number of key vantage points through which contemporary education discourses and practices can be understood 'globally' as mediated by the pedagogy of the consumer. More precisely, they allude to the geopolitical specificities and rationalities underpinning neo-liberal reform across different nations, regions and localities.

\section{Theory, Political Praxis and Stemming the Tide of Inequity}

In terms of making sense of global education trends, the above studies are invaluable conceptually and empirically, albeit variegated methodologically and analytically. This makes the 'global' an elusive subject matter for discussions of neo-liberalism. Hilgers (2010) identifies three types of conceptual and analytical approaches to the study of neo-liberalism, for example: cultural, systemic and governmental. Each of these approaches are characterised by a shared presupposition concerning the 'universal' content of the neo-liberal imaginary, namely ideas and practices underpinned by deregulation, marketisation, consumerism and competition. At the same time, they differ inasmuch as they employ specific analytical frameworks and epistemologies through which to ground discussions of the discursive and material effects pertaining to neo-liberal governance. Coupled with such analytical diffuseness is the fact that "neo-liberalism is heartless - both metaphorically and analytically" (Clarke, 2008, p. 140). That is to say, neoliberalism lacks agency, a core or final authority because power is exercised through the character of networks, figurations and flows. In the case of some education systems, power to govern schools is shifted away from centrally planned institutions (such as local authorities) and dispersed through networks consisting of governing bodies, sponsors, private contractors, community stakeholders and parents (see Wilkins, 2012b). In other words, power can be characterised as "rhizomatic" (Deleuze \& Guattari, 1980): it is deployed and modulated through the exercise of a whole set of applications and techniques located in vertical and horizontal networks of connection and co-habitation. From this perspective, there is no centralised authority that singularly exercises responsibility for the big transformations produced by neo-liberalism (hence the frustration tied to linking the cause and effect proper to late capitalism, see Fisher, 2009).

A corollary of this is that elements of risk, stress and even failure become 
increasingly individualised and, more recently, de-socialized as symptomatic of hardwired or "irrational" behaviour. (Note for example the recent shift in British government towards the adoption of policy discourses modelled on "libertarian paternalism", a form of state intervention that envisions enhancing personal responsibility by increasing the "rational" responses of consumers to the market, see Wilkins, 2012c). In this framing agency is mystified in its relation to larger social structures as governments seek to disperse state power and relinquish those forms of protection and safeguarding formerly sanctioned by post-war social democratic welfare states (see Clarke $\&$ Newman, 1997). On this account, and the accounts provided by the contributing authors to this special issue, neo-liberal discourse performs a vital discursive role in de-politicizing human behaviour and abandoning as credulous any measure of the material and cultural forces that bear upon such constructions. A consequence of this is that the state further absolves itself of collective responsibility and citizens are burdened with the risks generated through late capitalism. (Note for example the volatile and unaccountable risks produced through unchecked financial speculation leading up to the financial crisis in 2008 , with the economy only to be later revived by taxpaying publics). The formation of these relations and tensions are neatly captured through the theme of "governmentalisation" pursued by Foucault (1979) in which he conceptualized power as both totalizing and individualizing. Totalizing because state power is exercised through a field of instruments and technologies geared towards summoning at a distance citizens as governable subjects (see also Miller $\&$ Rose, 2008); and individualising because it relies on subjects both internalising the rules by which they are governed and engaging with these behavioural norms as frameworks for adjudicating the systems of codes by which they practise self-governing. Through a governmentality lens, neo-liberalism can therefore be characterised as a pedagogical force or governmental technology aimed at reaching into the 'soul' of citizens and rendering them self-governing, "willing selves".

For theoreticians and political commentators, this raises serious difficulties over the specificity of neo-liberalism as a political-cultural project, which can be analysed at best as fragmentary, nebulous, abstract and impersonal. This has led to genuine concerns that "neo-liberalism" as an umbrella term for encompassing trends of deregulation and marketisation in the realm of welfare is unsatisfactory; that it is too reductionist, sweeping and fails to grapple with the complexity of internal systems that provisionally constitute the trajectory and development of modern forms of statecraft. While these criticisms of the term neo-liberalism are well founded, they fail to consider what is at stake if we dispense with the term neo-liberalism. In light of the above observations, it is imperative to engage in critical forms of dialogue 
and analysis, the kinds of feminist-inspired discourse that force us to think about the ways in which the "personal is political". When we consider the neo-liberal drive towards deregulation and atomistic individualisation for example (a process in which homo economicus is dominant and cultural tastes and preferences are reduced to expressions of market choice) the language of critical theory offers possibilities for articulating what is beyond the limits and language of free market ideology. It enables us to grapple with those deregulated forces which are impacting economies and peoples, and which are constraining the social and democratic hopes underpinned by welfare politics, policies and practices. As eminent cultural theorist Stuart Hall argues, "I sympathise with this critique [of neo-liberalism]. However, I think there are enough common features to warrant giving it a provisional conceptual identity, provided this is understood as a first approximation. Even Marx argued that analysis yields understanding at different levels of abstraction, and critical thought often begins with a "chaotic" abstraction though we then need to add "further determinations" in order to "reproduce the concrete in thought". I would also argue that naming neoliberalism is politically necessary, to give resistance content, focus and a cutting edge" (2011, p. 9).

\section{References}

Barnett, C., Clarke, N. Cloke, P., \& Malpass, A. (2008). The elusive subjects of neoliberalism: Beyond the analytics of governmentality. Cultural Studies, 22 (5), 624-653. Bevir, M. (2007). The construction of governance. In M. Bevir, \& F. Brentmann (Eds.) Governance, consumers and citizens: Agency and resistance in contemporary politics. Hampshire and New York: Palgrave Macmillan.

Boudreau, J-A., Keil, R., \& Young, D. (2009). Changing Toronto: Governing urban neoliberalism. University of Toronto Press: Higher Education Division

Brown, W. (2006). American nightmare: Neoliberalism, neoconservatism, and dedemocratization. Political Theory, 34 (6), 690-714.

Burke, P. J. (2012). The right to higher education: Beyond widening participation. London: Routledge.

Clarke, J. (2007). Subordinating the social? Neo-liberalism and the remaking of welfare capitalism. Cultural Studies, 21 (6), 974-987.

Clarke, J. (2008). Living with/in and without neo-liberalism. Focaal-European Journal of Anthropology, 51, 135-147.

Clarke, J \& Newman, J. (1997). The Managerial state. London: Sage.

Clarke, J., Newman, J., Smith, N., Vidler, E., \& Westmarland, L. (2007). Creating citizen-consumers: Changing publics and changing public services. London: Sage.

Deacon, A. (1994). Perspectives on welfare. Buckingham: Open University Press. 
Ferguson, J., \& Gupta, A. (2002). Spatializing states: toward an ethnography of neoliberal governmentality. American Ethnologist, 29 (4), 981-1002.

Fisher, M. (2009). Capitalist realism. Is there no alternative?. Winchester, UK: Zero Book. Friedman, M. (1970). The counter - revolution in monetary theory. Institute of Economic Affairs: London.

Foucault, M. (1979.) Governmentality. Ideology and Consciousness 6, 5-21.

Deleuze, G., \& Guattari, F. (1980). A Thousand plateaus. Trans. B. Massumi. Continuum: London and New York.

Fanghanel, J. (2007). Investigating university lecturers' pedagogical constructs in the working context. HEA: York.

Freire, P. (1970). Pedagogy of the oppressed. Penguin Books: London.

Gewirtz, S., Ball, S.J., \& Bowe, R. (1995). Markets, choice and equity in education. Buckingham: Open University Press.

Giroux, H.A. (2004). Cultural studies, public pedagogy, and the responsibility of intellectuals. Communication and Cultural/Critical Studies, 1 (1), 59-79.

Giroux, H.A. (2011). Education and the crisis of public values: Challenging the attack on teachers, students, and public education. Peter Lang: New York.

Gray, J. (2007). Enlightenment's wake. Politics and culture at the close of the modern age. Routledge: London.

Hall, S. (2011). The neoliberal revolution. Soundings, 48, 9-27.

Harvey, D. (2005) A Brief history of neoliberalism. Oxford: Oxford University Press.

Hilgers, M. (2010). The three anthropological approaches to neoliberalism. International Social Science Journal 61 (202), 351-364.

Hirschman, A.O. (1991). The rhetoric of reaction. Cambridge, MA: Bleknap Harvar.

Holland, D., \& Lave, J. (2000). History in person: An Introduction. In D. Holland \& J. Lave (Eds.) History in person: Enduring struggles, contentious practices, intimate identities. Sante Fe, New Mexico: School of American Research Press.

Holm, A-S., \& Arreman, I. E (2011). Privatisation of public education? The emergence of independent upper secondary schools in Sweden. Journal of Education Policy, 26 (2), 225-243.

Johansson, H., \& Hvinden, B. (2005). Welfare governance and the remaking of citizenship. In J. Newman (Ed.) Remaking governance: Peoples, politics and the public sphere. University of Bristol, Bristol: Policy Press.

Kaščák, O., \& Pupala, B. (2011). Governmentality - Neoliberalism - Education: the Risk perspective. Journal of Pedagogy, 2 (2), 145-158.

Keat, R., \& Abercrombie, N. (Eds.) (1991). Enterprise culture. London: Routledge.

Lowe, R. (2005). Education. In P. Addison \& H. Jones (Eds.) A Companion to contemporary Britain 1939-2000. Oxford: Blackwell.

Mann, S. (2005). Alienation in the learning environment: a failure of community?. Studies in Higher Education, 30 (1), 43-55. 
Mccafferty, P. (2010). Forging a 'neoliberal pedagogy': The 'enterprising education' agenda in schools. Critical Social Policy, 30 (4), 541-563.

Mclean, M. (2006). Pedagogy and the university: Critical theory and practice. London: Continuum

Middlemas, K. (1986). Power, competition and the state. Volume 1: Britain in Search of Balance, 1940-61. Macmillan Press: London

Miller, P., \& Rose, N. (2008). Governing the present. administering economic, social and personal life. Policy Press: Cambridge

Newman, J. (2007). Governance as cultural practice: Text, talk and the struggle for meaning. In M. Bevir and F. Trentmann (Eds.) Governance, consumers and citizens: Agency and resistance in contemporary politics. Hampshire and New York: Palgrave Macmillan

Olssen, M., Codd, J., \& O’Neill, A-M. (2004). Education policy: Globalization, citizenship and democracy. London: Sage

Ong, A. (2006). Neoliberalism as exception: Mutations in citizenship and sovereignty. Durham, DC: Duke University Press

Peck, J. (2004). Geography and public policy: constructions of neoliberalism. Progress in Human Geography, 28 (3), 392-405.

Peck, J., \& Tickell, A. (2002). Neoliberalizing space. Antipode 34 (3), 380-404.

Rose, N. (1999). Powers of freedom. Cambridge: Cambridge University Press

Waquant, L. (2009). Punishing the poor: The Neoliberal government of social insecurity. Durham and London: Duke University Press

Wilkins, A. (2010). Citizens and/or consumers: Mutations in the construction of meanings and practices of school choice. Journal of Education Policy, 25 (2), 171-189.

Wilkins, A. (2012a). School choice and the commodification of education: A Visual approach to school brochures and websites. Critical Social Policy. Special Issue: Inequalities and Images: Insights for Policy and Practice, 32 (1), 70-87.

Wilkins, A. (2012b). Public battles and private takeovers: Academies and the politics of educational governance. Journal of Pedagogy, 3 (1), 11-29.

Wilkins, A. (2012c) Libertarian paternalism: Policy and everyday translations of the rational and the affective. Critical Policy Studies. Under Review

Wilkins, A. (2012d). The spectre of neoliberalism: Pedagogy, gender and the construction of learner identities. Critical Studies in Education, 53 (2), 197-210.

\section{Author:}

Andrew Wilkins, Ph.D., Research Fellow

Roehampton University

Department of Education

Roehampton Lane

London

SW15 5PU

UK

email: andrew.wilkins@roehampton.ac.uk 